Portland State University

PDXScholar

\title{
Julie Guthman: Weighing In: Obesity, Food Justice, and the Limits of Capitalism
}

Amy K. Coplen

Portland State University, acoplen@pdx.edu

Follow this and additional works at: https://pdxscholar.library.pdx.edu/usp_fac

Part of the Food Studies Commons

Let us know how access to this document benefits you.

Citation Details

Coplen, A. K. (2013). Julie Guthman: Weighing in: obesity, food justice, and the limits of capitalism. Agriculture and Human Values, 30(3), 485-486.

This Book Review is brought to you for free and open access. It has been accepted for inclusion in Urban Studies and Planning Faculty Publications and Presentations by an authorized administrator of PDXScholar. Please contact us if we can make this document more accessible: pdxscholar@pdx.edu. 


\section{Julie Guthman: Weighing In: Obesity, Food Justice, and the Limits of Capitalism University of California Press, Berkeley, CA, 2011, 227 pp, ISBN 978-0-520-26625-4}

\section{Amy K. Coplen}

Amy K. Coplen is a recent graduate of the Master of Environmental Management program at Yale University where she studied food systems and the role of community gardens in building social cohesion. She is beginning doctoral work in Urban Studies at Portland State University as an IGERT fellow.

\section{Amy K. Coplen}

Doctoral Candidate and IGERT Fellow, Nohad A. Toulan School of Urban Studies and Planning, Portland State University, P.O. Box 751-USP, Portland, OR 97207-0751 e-mail: akcoplen@gmail.com

Guthman's Weighing In is a much-needed critical analysis of the dominant discourse surrounding the so-called “obesity epidemic”. By examining nutritional, medical, political, and capitalist contributions to what has essentially become a nondebate, Guthman explains how the public came to speciously conceptualize obesity as a product of inadequate nutritional education, poor personal choice, and lack of will power. Further, Guthman demonstrates how this conceptualization precludes the discovery of the actual causes of obesity. The analysis is complemented by well-chosen quotes from Guthman’s research subjects, which illustrate the biased, engrained, and fearful perceptions of healthism and body normativity that dominate food-focused academia, food policy, and our culture at large. Guthman reveals that the very institutions, movements, and alternatives in place to combat obesity through the promotion of "good food” are, in effect, perpetuating obesity, injustice, and a broken food system.

Guthman problematizes obesity using scant ethnographic data comprised mostly of journal entries from her undergraduate students, but within a robust theoretical framework and comprehensive political ecology approach. She interrogates the scientific, socio-cultural, and political-economic contributions to the dominant understanding of 
obesity. Her probe begins by debunking the very measurement by which obesity is defined: Body Mass Index (BMI). Guthman cites a BMI criteria shift made by the National Institutes of Health in 1998, that reclassified several million Americans as “overweight overnight”, thereby falsely indicating an “obesity epidemic” (p. 31). Guthman argues that the majority of obesity research is coproductive, that is, it assumes the cause of the problem (i.e., bad personal behavior), ignores the possibility of other causes, and thereby perpetuates prejudiced science (p. 33-34). Other causes? you might ask? Isn't obesity simply a product of excess calorie intake and a dearth of physical activity? Guthman has us question the use of this simplistic energy balance model to explain obesity, pointing to the lack of scientific evidence that Americans are, in fact, eating more and moving less than they did a generation ago (p. 92). Further, she points to emerging scientific evidence that environmental toxins, some products and byproducts of the food system itself, are contributing to obesity and other serious health outcomes (p. 100-101).

Guthman challenges the popular “obesogenic environment theory”, which attributes obesity to an overabundance of convenient, cheap, tasty, fattening foods and thwarts engagement in physical activity (p. 66). She aptly notes that many cultural, economic, and environmental contributors are left out of the equation. including how race and class manufacture obesogenic environments and vice versa. Consequently, efforts to make obesogenic environments more like "leptogenic” environments, or landscapes that purportedly provide an abundance of healthy foods and exercise opportunities, are likely to be ineffective in reducing body size. Pushing community gardens, farmers markets and other amenities, she argues, risks perpetuating a cycle of gentrification and displacement.

Arguing that obesity is an ecological condition (i.e., one deeply rooted in the political, economic, social, and natural environments), she examines the roles that corporations and the state play in constructing polluted and resource-limited built environments and a degraded foodscape. Furthermore, she accuses the alternative food movement, including the branch of food justice, of being complicit in perpetuating the injustices of capitalism and the state and thereby contributing to obesity. She posits that 
the missionary-like zeal with which the mantra of "good food" is hailed perpetuates the perception of obesity as a result of bad personal choices and sustains the problematization of non-normative bodies.

By focusing on nutrition education and market-based solutions to alleviating the environmental and social justice woes of the industrial food system, Guthman argues that foodies position themselves as morally and ethically superior to their overweight counterparts, whether this is their intention or not. This false sense of do-gooding and moralization is not innocuous, she contends. Opting out of the industrial food system, Guthman claims, is a failure to challenge the inferior foodscape of those who cannot access the alternative. Convinced that healthism and personal choice is the path to thin, the alternative food movement unwittingly lays blame on the victims, rather than the perpetrators, of the industrial system and fails to hold corporations and the state responsible for creating a food system that is healthy for everyone.

And everyone stands to lose both from our current food system, which is polluting the environment and our bodies in ways we are only beginning to understand, and from our obsession with obesity. The focus on obesity ignores the myriad other illnesses caused by poor quality food, inadequate access to healthcare, and environmental toxins particularly endocrine disruptive chemicals (EDCs) from a variety of synthetic chemicals. EDCs have not only been linked to fat tissue development and disruptions in appetite and metabolism, but also reproductive and behavioral disorders and cancers (p. 104).

Guthman begs us to take a step back from the obesity non-debate, to take our energy balance model blinders off, and to consider the full context and other potential causes of obesity. She compellingly argues that we are operating with a dangerously oversimplified view of the problem, one which is riddled with so many unquestioned assumptions about the causes of obesity that it is inherently biased, self-serving, and counterproductive. By promoting change in individual behavior through education, not only do we fail to hold the political economy responsible for perpetuating food injustice and a broken food system, but we miss the boat entirely. Guthman demands that we stop 
looking to market-based solutions for what are ultimately a product of capitalist motivations and ineffective policy and regulation. To create lasting change, we must work towards reform. Dizzyingly, Guthman proves that required reform goes well beyond the food system and must include a focus on employment, housing, finance, education, and healthcare, to name a few, that perpetuate race and class divisions in this country. Food academics and activists alike would be wise to consider Guthman's critique when developing future research and advocating for lasting food system change. 